\title{
TANGGUNG JAWAB HUKUM BIRO PERJALANAN UMRAH TERHADAP CALON JAMAAHNYA
}

\author{
Jeremi Korayan \\ Mahasiswa Program S1 Fakultas Hukum Universitas Tarumanagara \\ (Email: jeremikorayan@yahoo.com)
}

\section{Gunawan Djayaputra}

(Corresponding Author)

(Dosen Hukum Perdata Fakultas Hukum Universitas Tarumanagara, Meraih Sarjana Hukum

(S.H.) dari Fakultas Hukum Universitas Indonesia, Magister Hukum (M.H.) dari Fakultas Hukum

Universitas Indonesia, Doktor Ilmu Hukum (Dr.) dari Fakultas Hukum Universitas Indonesia)

(Email: gunawand@fh.untar.ac.id)

\begin{abstract}
As a legal subject, Umroh organizing agency has the legal responsibility of Umroh congregation, responsibilities relating to the concept of legal obligations. A person is legally responsible for a particular act or that he or she assumes legal liability means that he or she is responsible for a sanction in the event of a conflicting action. From legal aspect, Umroh organizing agency's legal responsibility can be seen from civil, criminal, and administrative aspects. Many of the Umroh organizing agency although it has permission from the government but in its implementation is not in accordance with the provisions set forth in the legislation regulating the implementation of Hajj and Umroh. This can result in losses for pilgrims who use the umroh organizing agency. For example, in practice, many Umroh organizing angency do not give written agreements. The agreement is usually done with a verbal agreement promising. Therefore, when the rights and obligations of the parties is not met, there is no authentic evidence to prosecute and no limits on liability. Actually, a written contract is regulated and stipulated in Article 45 of Law. 13/2008 on Organizing Haj Pilgrimage to Mecca. Thus the form of agreement of appointment of departure between the Umroh organizers agency with prospective pilgrims so that umroh can be known various responsibilities of the umroh organizers agency in case of incompatibility between the agreement with the realization.
\end{abstract}

Keywords: Responsibility, Umroh Organizing Agency, Umroh Congregation 


\section{PENDAHULUAN}

\section{A. Latar Belakang}

Masyarakat Indonesia yang merupakan mayoritas muslim dan menjadi negara berpenduduk agama Islam terbesar di dunia, maka sebagai masyarakat muslim wajiblah melaksanakan rukun Islam, salah satunya adalah rukun islam yang terakhir yaitu kewajiban melaksanakan ibadah haji dan umrah.

Haji dan umrah merupakan salah satu ibadah yang diwajibkan bagi setiap muslim yang mampu. ${ }^{1}$ Kewajiban ini merupakan rukun Islam yang kelima. Karena haji merupakan kewajiban, maka apabila orang yang mampu tidak melaksanakannya maka berdosa dan apabila melaksanakannya mendapat pahala.

Dalam Pasal 9 Peraturan Pemerintah Republik Indonesia Nomor 79 tahun 2012 tentang Pelaksanaan Undang-Undang Nomor 13 tahun 2018 tentang Penyelenggaraan Ibadah Haji, ibadah umrah adalah umrah yang dilaksanakan diluar musim haji. Penyelenggaraan Perjalanan Ibadah Umrah bertujuan memberikan pembinaan, pelayanan, dan perlindungan kepada Jemaah, sehingga Jemaah dapat menunaikan ibadahnya sesuai dengan ketentuan syariat, berdasarkan Pasal 3 Peraturan Menteri Agama Republik Indonesia Nomor 8 tahun 2008 tentang penyelenggaraan perjalanan ibadah umrah.

Minat masyarakat untuk melakukan ibadah umrah begitu tinggi, data pada tahun 2015 menurut Badan Pusat Statistik (BPS) menunjukkan jumlah jamaah umrah mencapai 154.455 (seratus lima puluh empat ribu empat ratus lima puluh lima) orang atau rata-rata setiap hari sebanyak 423 (empat ratus dua puluh tiga) jamaah umrah yang berangkat ke Arab Saudi. ${ }^{2}$

\footnotetext{
${ }^{1}$ Abdurachman Rochimi, Segala Hal Tentang Haji Dan Umroh. (Jakarta: PT. Gelora Aksara Pratama, 2010). h. 9

${ }^{2}$ Badan Pusat Statistik, "Jumlah Jamaah Umrah Tahun 2015," https://www.bps.go.id/linkTableDinamis/view/id/894. Diakses pada 5 April 2018
} 
Jumlah jamaah umrah dari Indonesia tercatat rata-rata setap bulannya mencapai 12.871 (dua belas ribu delapan ratus tujuh puluh satu) orang atau rata-rata ada 423 (empat ratus dua puluh tiga) jamaah umrah yang terbang ke Arab Saudi setiap harinya. Jumlah jamaah umrah ini diprediksi semakin banyak pada selama bulan puasa, awal Idul Fitri, dan hari-hari besar keagamaan Islam lainnya, serta hari libur sekolah. ${ }^{3}$

Perjalanan umrah yang semakin menjamur di Indonesia karena banyaknya jamaah umrah asal Indonesia yang ingin melaksanakan rukun islam kelima itu, dimanfatkan oleh pihak-pihak tertentu, sehingga dari sekian banyak biro perjalanan umrah yang ada perlu diteliti apakah biro perjalanan umrah tersebut legal artinya mendapat izin dari Kementerian Agama RI atau justru ilegal, jangan sampai masyarakat tertipu dengan tawaran-tawaran yang menggiurkan dengan harga murah dari pihak biro perjalanan umrah akan tetapi pada saat pelaksanaan justru malah tidak jadi berangkat.

Seiring dengan begitu banyak jumlah jamaah umrah maka berbanding lurus dengan banyaknya jumlah biro perjalanan umrah mengakibatkan persaingan antara biro penyelenggara perjalanan umrah yang satu dengan biro yang lainnya, dimana masing-masing biro memiliki strategi tertentu sebagai upaya untuk mengalihkan perhatian masyarakat agar menggunakan jasa biro tersebut, seperti menjanjikan dengan fasilitas yang baik, biaya yang murah serta ketepatan keberangkatan.

Selain mengeluarkan izin, Kementerian Agama sebagai pelaksana dan penanggung jawab pelaksanaan ibadah haji dan umrah, terdapat beberapa travel yang menyediakan jasa perjalanan ibadah haji dan umrah yang telah mendapat izin dari Kementerian Agama untuk menjadi pelaksana haji dan umrah yang mematuhi segala aturan-aturan yang berlaku termasuk UU RI No. 13 Tahun 2008 tentang penyelenggaran haji dan umrah dan Peratuan

\footnotetext{
${ }^{3}$ Kementerian Agama, "Rata-Rata Jemaah Umrah Brangkat Perhari 195 Orang," https://haji.kemenag.go.id/v3/content/rata-rata-jemaah-umrah-berangkat perhari-195-orang. Diakses pada 5 April 2018
} 
Menteri Agama tentang pelaksanaan haji dan umrah, namun dalam pelaksanaannya tidak sedikit travel-travel yang telah mengantongi izin dari Kementerian Agama ini melakukan hal yang bertentangan dengan peraturan perundang-undangan maupun Peraturan Pemerintah.

Banyak pihak biro penyelenggaraan ibadah umrah meskipun memiliki izin akan tetapi dalam pelaksanaannya tidak sesuai dengan ketentuan yang telah ditetapkan dalam peraturan perundang-undangan yang mengatur penyelenggaraan ibadah haji dan umrah. Hal tersebut dapat mengakibatkan kerugian bagi calon jamaah yang menggunakan biro jasa tersebut. Sebagai contoh dalam praktiknya, banyak pihak biro penyelenggaraan ibadah umrah tidak melakukan atau memberikan perjanjian secara tertulis yang menjelaskan jadwal keberangkatan dan kepulangan, fasilitas yang diperoleh, dan lain sebagainya.

Perjanjian tersebut biasa dilakukan dengan perjanjian lisan yang menjanjikan jika tahun ini mendaftar maka tahun depan akan berangkat atau dengan janji biaya murah dan mendapat fasilitas yang memuaskan. Sehingga apabila hak dan kewajiban para pihak tidak terpenuhi, tidak ada bukti otentik untuk menuntut dan tidak adanya batasan tanggung jawab.

Dalam pelaksanaan pemberangkatan calon jamaah umrah yang di lakukan oleh pihak biro penyelenggara ibadah umrah dengan calon jamaah umrah digunakan suatu perjanjian. Perjanjian pada dasarnya adalah suatu peristiwa dimana seseorang berjanji kepada seorang lain atau dimana dua orang itu saling berjanji untuk melaksanakan suatu hal. Dari peristiwa ini, timbulah suatu hubungan antara dua orang tersebut yang dinamakan perikatan. Perjanjian itu menerbitkan suatu perikatan antara dua orang yang membuatnya.

Bentuk perjanjian itu berupa suatu rangkaian perkataan yang mengandung janji-janji atau kesanggupan yang diucapkan atau ditulis. Dengan demikian hubungan antar perikatan dan perjanjian adalah bahwa 
perjanjian itu menerbitkan perikatan. Perjanjian adalah sumber perikatan, disampingnya sumber-sumber lain. ${ }^{4}$

Perikatan antara biro penyelenggara ibadah umrah dengan calon jamaah umrah selanjutnya didahului dengan perjanjian diantara para pihak, yang didalam perjanjian tersebut memuat syarat-syarat, hak, dan kewajiban para pihak. Perjanjian yang dibuat tersebut mengikat kedua belah pihak yaitu antara perusahaan atau biro penyelenggara ibadah umrah sebagai pihak pertama dengan calon jamaah umrah sebagai pihak kedua. Agar pelaksanaan suatu perjanjian dapat berjalan dengan baik maka untuk menentukan apakah debitur telah melaksanakan kewajiban memenuhi isi perjanjian ukurannya didasarkan pada kepatuhan, ini artinya debitur telah melaksanakan kewajibannya menurut yang sepatutnya, serasi, dan layak menurut semestinya seseuai dengan ketentuan yang telah mereka setujui bersama dalam perjanjian. ${ }^{5}$

Dengan demikian bentuk perjanjian pelaksanaan pemberangkatan antara pihak biro penyelenggara perjalanan umrah dengan calon jamaah umrah sehingga dapat diketahui berbagai tanggung jawab dari pihak biro penyelenggara apabila terjadi ketidaksesuaian antara perjanjian dengan realisasinya.

Berdasarkan hal tersebut diatas, maka Penulis mengangkat fenomena ini dalam penelitian skripsi Penulis yang berjudul “TANGGUNG JAWAB HUKUM BIRO PERJALANAN UMRAH TERHADAP CALON JAMAAHNYA".

\section{B. Perumusan Masalah}

\footnotetext{
${ }^{4}$ Subekti, 2002, Hukum Perjanjian, Jakarta,PT,Intermasa, Hal. 1.

${ }^{5}$ M. Yahya Harahap, 1986, Segi-Segi Hukum Perjanjian, Bandung: Alumni, Hal. 19.
} 
Berdasarkan dari latar belakang yang telah dipaparkan sebelumnya, maka dapat dirumuskan menjadi beberapa pokok masalah. Permasalahan yang akan dibahas yaitu:

1. Bagaimana tanggung jawab hukum biro perjalanan umrah terhadap calon jamaahnya?

2. Bagaimana akibat hukum atas gagal berangkatnya calon jamaah umrah yang diakibatkan oleh biro perjalanan umrah?

\section{PEMBAHASAN}

\section{A. Tanggung Jawab Hukum}

1. Pengertian Tanggung Jawab Hukum

Menurut Kamus Besar Bahasa Indonesia (KBBI) tanggung jawab adalah kewajiban menanggung segala sesuatunya bila terjadi apa-apa boleh dituntut, dipersalahkan, dan diperkarakan. Dalam kamus hukum, tanggung jawab adalah suatu keseharusan bagi seseorang untuk melaksanakan apa yang telah diwajibkan kepadanya. ${ }^{7}$ Konsep tanggung jawab hukum berkaitan erat dengan konsep hak dan kewajiban. ${ }^{8}$ Konsep hak merupakan suatu konsep yang menekankan pada pengertian hak yang berpasangan dengan pengertian kewajiban. Pendapat yang umum mengatakan bahwa hak pada seseorang senantiasa berkorelasi dengan kewajiban pada orang lain. ${ }^{9}$

Sebuah konsep yang berkaitan dengan konsep kewajiban hukum adalah konsep tanggung jawab (pertanggung jawaban) hukum. Bahwa seseorang bertanggung jawab secara hukum atas perbuatan tertentu atau bahwa dia memikul tanggung jawab hukum, artinya dia bertanggung

\footnotetext{
${ }^{7}$ Andi Hamzah, Kamus Hukum, Ghalia Indonesia, 2005.

${ }^{8}$ Satjipto Rahardjo, Ilmu Hukum, PT. Citra Aditya Bakti, Bandung: 2000, hlm 55

${ }^{9}$ Ibid, hlm 57
} 
jawab atas suatu sanksi bila perbuatannya bertentangan dengan peraturan yang berlaku. ${ }^{10}$

Menurut hukum perdata dasar pertanggungjawaban dibagi menjadi dua macam, yaitu kesalahan dan risiko. Dengan demikian dikenal dengan pertanggung jawaban atas dasar kesalahan (lilability without based on fault) dan pertanggung jawaban tanpa kesalahan yang dikenal (lilability without fault) yang dikenal dengan tanggung jawab risiko atau tanggung jawab mutlak (strick liabiliy). ${ }^{11}$

Prinsip dasar pertanggung jawaban atas dasar kesalahan mengandung arti bahwa seseorang harus bertanggung jawab karena ia melakukan kesalahan karena merugikan orang lain. Sebaliknya prinsip tanggung jawab risiko adalah bahwa konsumen penggugat tidak diwajibkan lagi melainkan produsen tergugat langsung bertanggung jawab sebagai risiko usahanya.

2. Teori Tanggung Jawab Hukum

Menurut Abdulkadir Muhammad teori tanggung jawab dalam perbuatan melanggar hukum (tort liability) dibagi menjadi beberapa teori, yaitu: ${ }^{12}$

1. Tanggung jawab akibat perbuatan melanggar hukum yang dilakukan dengan sengaja (intertional tort liability), tergugat harus sudah melakukan perbuatan sedemikian rupa sehingga merugikan penggugat atau mengetahui bahwa apa yang dilakukan tergugat akan mengakibatkan kerugian.

2. Tanggung jawab akibat perbuatan melanggar hukum yang dilakukan karena kelalaian (negligence tort lilability), didasarkan pada konsep kesalahan (concept of fault) yang

\footnotetext{
${ }^{10}$ Hans Kalsen, Teori Umum tentang Hukum dan Negara, PT. Raja Grafindo Persada Bandung: 2006 hlm 95

${ }^{11}$ Ibid. hlm.49.

${ }^{12}$ Abdulkadir Muhammad, Hukum Perusahaan Indonesia, Citra Aditya Bakti, 2010, hlm. 503.
} 
berkaitan dengan moral dan hukum yang sudah bercampur baur (interminglend).

3. Tanggung jawab mutlak akibat perbuatan melanggar hukum tanpa mempersoalkan kesalahan (stirck liability), didasarkan pada perbuatannya baik secara sengaja maupun tidak sengaja, artinya meskipun bukan kesalahannya tetap bertanggung jawab atas kerugian yang timbul akibat perbuatannya.

\section{B. Wanprestasi}

Dari aspek hukumnya, perjanjian yang sudah dibuat dan disepakati oleh para pihak berlaku sebagai undang-undang dan mengikat para pihak yang membuatnya (Pasal 1338 KUHPer). Oleh karenanya setiap perjanjian yang dibuat harus benar-benar dilaksanakan. Kalau tidak, maka akan dikategorikan sebagai perbuatan wanprestasi atau ingkar janji yang memberikan hak kepada pihak yang dirugikan untuk menuntut ganti rugi. Selain alpa atau "lalai" atau ingkar janji, wanprestasi juga dapat berupa pelanggaran perjanjian atau berbuat sesuatu yang tidak boleh dilakukannya. Wanpestasi berasal dari bahasa Belanda, yang berarti prestasi buruk.

Wanprestasi (kelalaian atau kealpaan) dapat berupa empat macam:

a. Tidak melakukan apa yang disanggupi akan dilakukannya;

b. Melaksanakan apa yang dijanjikannya, tetapi tidak sebagaimana dijanjikan;

c. Melakukan apa yang dijanjikannya tetapi terlambat;

d. Melakukan sesuatu yang menurut perjanjian tidak boleh dilakukannya.

Terhadap kelalaian atau kealpaan diancamkan beberapa sanksi atau hukuman. Hukuman bagi pihak yang lalai ada empat macam, yaitu: ${ }^{13}$

\footnotetext{
${ }^{13}$ Subekti, Hukum Perjanjian, Cetakan ke-21. (Jakarta: Intermasa, 2005), hal. 17.
} 
a. Membayar kerugian yang diderita oleh pihak yang dirugikan atau dengan singkat dinamakan ganti rugi

b. Pembatalan perjanjian atau juga dinamakan pemecahan perjanjian;

c. Peralihan risiko;

d. Membayar biaya perkara, kalau sampai diperkarakan di depan hakim.

Kewajiban membayar ganti rugi (schade vergoeding) tersebut tidak timbul seketika terjadi kelalaian, melainkan baru efektif setelah pihak yang berkewajiban dinyatakan lalai (ingebrekestelling) dan tetap tidak melaksanakan prestasinya. Hal ini diatur dalam Pasal 1243 KUHPerdata yang pada pokokya menyatakan:

1. Pernyataan lalai tersebut harus berbentuk surat perintah atau akta lain yang sejenis, yaitu suatu salinan daripada tulisan yang telah dibuat lebih dahulu oleh juru sita dan diberikan kepada yang bersangkutan.

2. Berdasarkan kekuatan perjanjian itu sendiri.

3. Jika teguran kelalaian sudah dilakukan barulah menyusul peringatan atau anmaning yang biasa disebut sommasi.

Selanjutnya, disyaratkan kerugian yang dapat dituntut haruslah kerugian yang menjadi akibat dari wanprestasi. Antara kerugian dan wanprestasi harus ada hubungan sebab akibat. Kreditor harus dapat membuktikan besarnya kerugian yang dialami dan faktor penyebab kerugian tersebut adalah karena kelalaian debitor, nukan karena faktor diluar kemampuan debitor. ${ }^{14}$

\section{Perbuatan Melawan Hukum (Onrechtmatigedaad)}

\footnotetext{
${ }^{14}$ Ibid., hal. 71.
} 
Pasal 1365 KUHPerdata :

"Tiap perbuatan melanggar hukum, yang membawa kerugian kepada seorang lain, mewajibkan orang yang karena salahnya menerbitkan kerugian itu, mengganti kerugian tersebut."

Unsur-unsur dalam Pasal 1365 KUHPerdata adalah $:^{15}$

1. Perbuatan itu harus melawan hukum

Perbuatan yang dilakukan itu, harus melawan hukum. Bahwa perbuatan itu dapat berbuat sesuatu maupun tidak berbuat sesuatu. Berbuat atau tidak berbuat merupakan suatu perbuatan melawan hukum jika:

- Perbuatan melanggar Undang-Undang

- Perbuatan melanggar hak orang lain yang dilindungi hukum

Perbuatan yang bertentangan dengan hak orang lain termasuk salah satu perbuatan yang dilarang oleh Pasal 1365 KUHPerdata. Hak yang dilanggar tersebut adalah hak-hak seseorang yang diakui oleh hukum. Yang dimaksud dengan melanggar hak orang lain adalah melanggar hak subjektif orang lain, yaitu wewenang khusus yang diberikan oleh hukum kepada seseorang untuk digunakan bagi kepentingannya.

- Perbuatan yang bertentangan dengan kewajiban hukum si pelaku

Perbuatan ini juga termasuk ke dalam kategori perbuatan melawan hukum jika perbuatan tersebut bertentangan dengan kewajiban hukum dari pelakunya. Istilah kewajiban hukum ini yang dimaksudkan adalah bahwa suatu kewajiban yang diberikan oleh hukum terhadap seseorang, baik hukum tertulis maupun hukum tidak tertulis. Jadi, bukan hanya bertentangan dengan

${ }^{15}$ P.N.H. Simanjuntak, Pokok-Pokok Hukum Perdata Indonesia, Cetakan ke-1. (Jakarta: Djambatan, 1999), hal. 353-355. 
hukum tertulis melainkan juga bertentangan dengan hak orang lain menurut Undang-Undang.

- Perbuatan yang bertentangan kesusilaan

Dapat dinyatakan sebagai norma-norma moral yang dalam pergaulan masyarakat telah diterima sebagai normanorma hukum. Tindakan yang melanggar kesusilaan yang oleh masyarakat telah diakui sebagai hukum tidak tertulis juga dianggap sebagai perbuatan melawan hukum, manakala dengan tindakan melanggar kesusilaan tersebut telah terjadi kerugian bagi pihak lain, maka berdasarkan atas perbuatan melawan hukum.

- Perbuatan yang bertentangan sikap baik dalam masyarakat untuk memperhatikan kepentingan orang lain (bertentangan dengan kepatutan yang berlaku dalam lalu lintas masyarakat terhadap diri atau barang orang lain)

Perbuatan yang bertentangan dengan kehati-hatian atau keharusan dalam pergaulan masyarakat yang baik ini juga dianggap sebagai suatu perbuatan melawan hukum. Pada garis besarnya dapat dinyatakan bahwa suatu perbuatan adalah bertentangan dengan kepatutan, jika:

1) Perbuatan tersebut sangat merugikan orang lain

2) Perbuatan yang tidak berfaedah yang menimbulkan bahaya terhadap orang lain, yang menurut menusia yang normal hal tersebut harus diperhatikan

2. Perbuatan itu harus dilakukan dengan kesalahan

Kesalahan dapat berupa kesengajaan dan kelalaian. Kesengajaan berarti seseorang melakukan suatu perbuatan dan perbuatan ini berniat untuk membuat suatu akibat. Sedangkan kelalaian berarti seseorang tidak melakukan suatu perbuatan, padahal menurut hukum ia harus berbuat atau melakukan suatu perbuatan. Dengan kata lain dapat disimpulkan, bahwa : 
1) Kesengajaan adalah melakukan suatu perbuatan, di mana dengan perbuatan itu si pelaku menyadari sepenuhnya akan ada akibat dari perbuatan tersebut.

2) Kelalaian adalah seseorang tidak melakukan suatu perbuatan, tetapi dengan bersikap demikian pada hakekatnya ia telah melawan hukum, sebab semestinya ia harus berbuat atau melakukan suatu perbuatan. Jadi ia lalai untuk melakukan sesuatu perbuatan yang sebenarnya wajib melakukan suatu perbuatan.

3. Perbuatan itu harus menimbulkan kerugian

Dalam pengertian bahwa kerugian yang disebabkan oleh karena perbuatan melawan hukum dapat berupa :

A. Kerugian materiil

Kerugian materiil adalah kerugian yang dapat dinilai dengan uang, seperti kerugian yang nyata-nyata diderita dan keuntungan yang seharunya diperoleh.

B. Kerugian immateril

Kerugian immaterial adalah kerugian yang tidak dapat dinilai dengan uang seperti ketakutan, sakit dan kehilangan kesenangan hidup.

4. Perbuatan itu harus ada hubungan kausal (sebab-akibat)

Hubungan kausal merupakan hubungan sebab-akibat antara perbuatan melawan hukum dengan kerugian. Hubungan kausal ini tersimpul dalam Pasal 1365 KUHPerdata, bahwa perbuatan yang karena kesalahannya menyebabkan kerugian. Dengan demikian, kerugian itu harus timbul sebagai akibat dari perbuatan seseorang. Jika tidak ada perbuatan (sebabnya), maka tidak ada kerugian (akibatnya).

\section{Perjanjian pada Umumnya}




\section{Pengertian Perjanjian}

Pengertian Perjanjian diatur dalam Pasal 1313 yang berbunyi : "Perjanjian adalah suatu perbuatan dengan mana satu pihak atau lebih mengikatkan dirinya terhadap satu orang atau lebih". Soebekti mengemukakan pengertian perjanjian adalah suatu peristiwa dimana seorang berjanji kepada seseorang lain atau dimana orang itu saling berjanji untuk melaksanakan sesuatu hal. ${ }^{16}$ Sedangkan menurut Abdulkadir Muhammad mengemukakan bahwa perjanjian adalah suatu persetujuan dengan mana dua orang atau lebih mengikatkan diri untuk melaksanakan suatu hal di lingkungan lapangan harta kekayaan. ${ }^{17}$ Selanjutnya unsur-unsur perjanjian dapat dikatagorikan sebagai berikut: ${ }^{18}$

a. Adanya kaidah unsur hukum

Kaidah dalam perjanjian dapat dibagi menjadi dua macam yakni, tertulis dan tidak tertulis. Kaidah hukum tertulis adalah kaidah yang terdapat di dalam peraturan perundangundangan, traktat, dan yurisprudensi. Sedangkan perjanjian tidak tertulis adalah kaidah-kaidah hukum yang timbul, tumbuh, hidup dalam masyarakat seperti, jual beli emas, jual beli tanah dan lain sebagainya.

b. Subjek hukum

Istilah dari subjek hukum adalah recthpersoon. Recthpersoon diartikan sebagai pendukung hak dan kewajiban. Dalam hal ini yang menjadi subjek dalam kontrak adalah debitur dan kreditur. Kreditur adalah orang yang berpiutang, sedangkan debitur adalah orang yang berutang.

\footnotetext{
${ }^{16}$ R. Soebekti, Hukum Perjanjian, Intermesa, Jakarta, 2002, hlm. 1.

${ }^{17}$ Abdulkadir Muhammad, Hukum Perdata Indonesia, Citra Aditya Bakti, 2000, hlm. 76.

${ }^{18}$ Salim H.S, Hukum Kontrak Teori dan Tehnik Penyusunan Kontrak, Sinar Grafika, Jakarta, 2004, hlm 3 .
} 
c. Adanya prestasi

Prestasi adalah apa yang menjadi hak kreditur dan apa yang menjadi kewajiban debitur. Suatu prestasi berdasarkan Pasal 1234 KUHPerdata terdiri dari memberikan sesuatu, berbuat sesuatu, dan tidak berbuat sesuatu.

d. Kata sepakat

Berdasarkan Pasal 1320 KUHPerdata terdapat empat syarat sahnya perjanjian salah satunya adalah kata sepakat konseksus.

e. Akibat hukum

Setiap perjanjian yang dibuat oleh para pihak akan menimbulkan akibat hukum yang menimbulkan hak dan kewajiban.

2. Syarat-syarat Sahnya Perjanjian

Syarat-syarat yang harus dipenuhi agar perjanjian menjadi sah dan mengikat para pihak. Sebagaimana diatur dalam Pasal 1320 KUHPer, sebagai berikut: ${ }^{19}$ Untuk sahnya suatu perjanjian diperlukan 4 syarat:

1. Sepakat mereka yang mengikatkan dirinya.

2. Kecakapan untuk membuat suatu perikatan.

3. Suatu hal tertentu.

4. Suatu sebab yang halal.

Dua syarat yang pertama, dinamakan syarat subjektif karena mengenai orang- orang atau subjeknya yang mengadakan perjanjian, tidak dipenuhinya syarat subjektif akan mengakibatkan suatu perjanjian dapat dibatalkan, sedangkan dua syarat terahir dinamakan syarat-syarat objektif karena mengenai perjanjian sendiri atau objeknya dari perbuatan hukum yang dilakukan itu, ${ }^{20}$ apabila syarat objektifnya tidak dipenuhi akan mengakibatkan

\footnotetext{
${ }^{19}$ Subekti, Hukum Perjanjian, Cetakan ke-21. (Jakarta: Intermasa, 2005), hal. 17.

${ }^{20}$ Soebekti, Op.cit, hlm. 17.
} 
perjanjian tersebut batal demi hukum, artinya sejak semula dianggap tidak ada perjanjian tersebut.

Syarat Pertama "Sepakat mereka yang mengikat kandiri" berarti, para pihak yang membuat perjanjian harus sepakat atau setuju mengenai hal-hal pokok atau materi yang diperjanjikan, dimana kesepakatan itu harus dicapai dengan tanpa ada paksaan, penipuan atau kekhilafan (Pasal 1321 KUH Perdata). Misalnya, sepakat untuk melakukan jual-beli tanah, harganya, cara pembayarannya, penyelesaian sengketanya.

Syarat Kedua, "kecakapan untuk membuat suatu perikatan" Pasal 1330 KUHPer sudah mengatur pihak-pihak mana saja yang boleh atau dianggap cakap untuk membuat perjanjian, yang cakap atau yang dibolehkan oleh hukum untuk membuat perjanjian adalah orang yang sudah dewasa, yaitu sudah berumur genap 21 tahun (Pasal 330 KUHPer), dan orang yang tidak sedang di bawah pengampuan. Tak cakap untuk membuat suatu perjanjian adalah:

1. Orang yang belum dewasa.

2. Orang yang ditaruh dibawah pengampuan.

Syarat Ketiga "suatu hal tertentu" maksudnya adalah dalam membuat perjanjian, apa yang diperjanjikan (objek perikatannnya) harus jelas. Setidaknya jenis barangnya itu harus ada (lihat Pasal 1333 ayat (1)) yang dilarang undang-undang atau yang bertentangan dengan hukum,

Syarat Keempat "Suatu sebab yang halal" maksudnya adalah nilai-nilai kesopanan ataupun ketertiban umum (Pasal 1337 KUH Perdata). Jika sudah memenuhi ke empat syarat di atas, maka perjanjian tersebut adalah sah. Tapi, perjanjian bisa diminta dibatalkan bahkan batal demi hukum jika tidak memenuhi syarat ini. 
3. Asas-Asas Hukum Perjanjian

Keberadaan suatu perjanjian tidak terlepas dari asas-asas yang mengikutinya yang harus dijalankan oleh para pihak untuk menciptakan kepastian hukum. Didalam perjanjian terdapat 5 (lima) asas yang dikenal menurut hukum perdata yaitu: ${ }^{21}$

a. Asas kebebasan berkontrak (freedom of contract)

Asas kebebasan berkontrak dapat dianalisis dari ketentuan Pasal 1338 ayat (1) KUHPerdata, yang berbunyi :

"Semua perjanjian yang dibuat secara sah berlaku sebagai undangundang bagi mereka yang membuatnya."

Asas ini merupakan suatu asas yang memberikan kebebasan kepada para pihak untuk:

1) Membuat atau tidak membuat perjanjian;

2) Mengadakan perjanjian dengan siapa pun;

3) Menentukan isi perjanjian, pelaksanaan, dan persyaratan serta;

4) Menentukan bentuk perjanjiannya apakah tertulis atau lisan;

b. Asas konsesualisme (consensualism)

Asas konsesualis dapat disimpulkan dalam Pasal 1320 ayat (1) KUHPerdata. Pasal tersebut ditentukan bahwa salah satu syarat sahnya perjanjian adalah adanya kesepakatan antara kedua belah pihak. Asas ini merupakan asas yang menyatakan bahwa perjanjian tidak diadakan secara formal, melainkan cukup dengan adanya kesepakatan kedua belak pihak.

${ }^{21}$ Hardijan Rusli, Hukum Perjanjian Indonesia dan Common law, Sinar Harapan, Jakarta, 1996, hlm.6. 
c. Asas kepastian hukum (pucta sunt servanda)

Asas kepastian hukum disebut juga dengan asas pucta sunt servanda merupakan asas yang berhubungan dengan akibat perjanjian. Asas pacta sunst servanda merupakan asas bahwa hakim atau pihak ketiga harus menghormati substansi kontrak yang dibuat oleh para pihak, sebagai layaknya sebuah undang-undang. Mereka tidak boleh melakukan intervensi terhadap subtansi kontrak yang dibuat para pihak. Asas pucta sunt servanda sebagaimana pada Pasal 1338 ayat (1) KUHPerdata.

d. Asas itikad baik (good faith)

Asas itikad baik tercantum dalam Pasal 1338 ayat (3) KUHPerdata yang berbunyi: "Perjanjian harus dilaksanakan dengan itikad baik" asas ini merupakan asas bahwa para pihak, yaitu debitur dan kreditur harus melaksanakan subtansi kontrak berdasarkan kepercayaan atau keyakinan yang teguh maupun kemampuan baik dari para pihak. Asas itikad baik terbagi menjadi dua macam yakni, itikad baik nisbi dan itikad baik mutlak. Pada itikad yang pertama, seseorang memperhatikan sikap dan tingkah laku yang nyata dari subjek. Pada itikad yang kedua, penilaian terletak pada akal sehat dan keadilan serta dibuat ukuran yang objektif untuk menilai keadaan menurut norma-norma objektif.

e. Asas keperibadian (personality)

Asas keperibadian merupakan asas yang menunjukan bahwa seseorang yang akan melakukan dan membuat kontrak hanya untuk kepentingan perseorangan saja. Hal ini dapat dilihat Pasal 1315 dan Pasal 1340 KUHPerdata. Pada Pasal 1315 dan Pasal 1340 KUHPerdata menyatakan :

"Pada umumnya seseorang tidak dapat mengadakan perikatan atau perjanjian selain untuk dirinya sendiri." Kemudian pasal 1340 KUHPerdata menyatakan bahwa " Perjanjian hanya berlaku antara pihak yang membuatnya“" 


\section{E. Peraturan Perundang-undangan Yang Mengatur Tentang Penyelenggaraan Perjalanan Ibadah Umrah}

Peraturan perundangan-undangan yang mengatur tentang penyelenggaraan perjalanan ibadah umrah yaitu berdasarkan pada Undang-Undang Nomor 13 tahun 2008 tentang Penyelenggaraan Ibadah Haji, Peraturan Pemerintah Republik Indonesia Nomor 79 tahun 2012 tentang Pelaksanaan Pelaksanaan Undang-Undang no 13 tahun 2008 tentang Penyelenggaraan Ibadah Haji, Peraturan Menteri Agama Republik Indonesia Nomor 8 tahun 2018 tentang Penyelenggaraan Perjalanan Ibadah Umrah.

1. Penyelenggaraan Ibadah Umrah

Penyelenggaraan ibadah umrah menurut pasal 43 ayat 2 Undang-Undang Nomor 13 tahun 2008 tentang Penyelenggaraan Ibadah Haji, dapat diselenggarakan oleh pemerintah dan/atau biro perjalanan wisata yang ditetapkan oleh Menteri. Menurut pasal 1 angka 10 Peraturan Pemerintah Republik Indonesia Nomor 79 tahun 2012 tentang Pelaksanaan Undang-Undang no 13 tahun 2008 tentang Penyelenggaraan Ibadah Haji, yang dimaksud dengan penyelenggaraan perjalanan ibadah umrah adalah biro perjalanan wisata yang telah mendapat izin dari Menteri untuk menyelenggarakan perjalanan ibadah umrah. Menurut pasal 1 ayat 1 Peraturan Menteri Agama Republik Indonesia Nomor 8 tahun 2018 tentang Penyelenggaraan Perjalanan Ibadah Umrah, penyelenggaraan perjalanan ibadah umrah adalah rangkaian kegiatan perjalanan Ibadah Umrah di luar musim haji yang meliputi pembinaan, pelayanan, dan perlindungan Jemaah, yang dilaksanakan oleh pemerintah dan/atau penyelenggara perjalanan ibadah umrah.

2. Persyaratan Penyelenggaraan Perjalanan Umrah 
Menurut Pasal 5 ayat 2 Peraturan Menteri Agama Republik Indonesia Nomor 8 tahun 2018 tentang Penyelenggaraan Perjalanan Ibadah Umrah, Untuk memiliki izin operasional sebagai PPIU biro perjalanan wisata harus memenuhi persyaratan:

a. Memiliki akta notaris pendirian perseroan terbatas dan/atau perubahannya sebagai biro perjalanan wisata yang memiliki salah satu kegiatan usahanya di bidang keagamaan/perjalanan ibadah yang telah mendapat pengesahan dari Kementerian Hukum dan Hak Asasi Manusia;

b. Pemilik saham, komisaris, dan direksi yang tercantum dalam akta notaris perseroan terbatas merupakan warga negara Indonesia yang beragama Islam;

c. Pemilik saham, komisaris, dan direksi tidak pernah atau sedang dikenai sanksi atas pelanggaran Penyelenggaraan Perjalanan Ibadah Umrah;

d. Memiliki kantor pelayanan yang dibuktikan dengan surat keterangan domisili perusahaan dari pemerintah daerah dan melampirkan bukti kepemilikan atau sewa menyewa paling singkat 4 (empat) tahun yang dibuktikan dengan pengesahan atau legalisasi dari Notaris;

e. Memiliki tanda daftar usaha pariwisata;

f. Telah beroperasi paling singkat 2 (dua) tahun sebagai biro perjalanan wisata yang dibuktikan dengan laporan kegiatan usaha; 
g. Memiliki sertifikat usaha jasa perjalanan wisata dengan kategori biro perjalanan wisata yang masih berlaku;

h. Memiliki kemampuan teknis untuk menyelenggarakan perjalanan Ibadah Umrah yang meliputi kemampuan sumber daya manusia, manajemen, serta sarana dan prasarana;

i. Memiliki laporan keuangan perusahaan 2 (dua) tahun terakhir dan telah diaudit akuntan publik yang terdaftar di Kementerian Keuangan dengan opini wajar tanpa pengecualian;

j. Melampirkan surat keterangan fiskal dan fotokopi nomor pokok wajib pajak atas nama perusahaan dan pimpinan perusahaan;

k. Memiliki surat rekomendasi asli dari Kantor Wilayah dengan masa berlaku 3 (tiga) bulan; dan

1. Menyerahkan jaminan dalam bentuk deposito/ bank garansi atas nama biro perjalanan wisata yang diterbitkan oleh bank syariah dan/atau bank umum nasional yang memiliki layanan syariah dengan masa berlaku 4 (empat) tahun.

3. Kewajiban Penyelenggara Perjalanan Ibadah Umrah

Kewajiban penyelenggara perjalanan ibadah umrah diatur dalam Pasal 45 ayat 1 Undang-Undang Nomor 13 tahun 2008 tentang Penyelenggaraan Ibadah Haji, bahwa penyelenggara perjalanan ibadah umrah wajib memenuhi ketentuan berikut:

1. Menyediakan pembimbing ibadah dan petugas kesehatan; 
2. Memberangkatkan dan memulangkan jemaah sesuai dengan masa berlaku visa umrah di Arab Saudi dan ketentuan peraturan perundang- undangan;

3. Memberikan pelayanan kepada jemaah sesuai dengan perjanjian tertulis yang disepakati antara penyelenggara dan jemaah; dan

4. Melapor kepada Perwakilan Republik Indonesia di Arab Saudi pada saat datang di Arab Saudi dan pada saat akan kembali ke Indonesia.

4. Larangan Penyelenggara Perjalanan Ibadah Umrah

Larangan penyelenggara perjalanan ibadah umrah diatur dalam Pasal 12 Peraturan Menteri Agama Republik Indonesia Nomor 8 tahun 2018 tentang Penyelenggaraan Perjalanan Ibadah Umrah yaitu Penyelenggara Perjalanan Ibadah Umrah (PPIU) dilarang memfasilitasi keberangkatan jemaah menggunakan Biaya Penyelenggaraan Ibadah Umrah (BPIU) yang berasal dari dana talangan.

Menurut Pasal 65 Peraturan Pemerintah Republik Indonesia Nomor 79 tahun 2012 tentang Pelaksanaan Undang-Undang Nomor 13 tahun 2018 tentang Penyelenggaraan Ibadah Haji, diatur mengenai larangan bagi penyelenggara perjalanan ibadah umrah, untuk menelantarkan jemaah umrah yang mengakibatkan jemaah umrah:

1. Gagal berangkat ke Arab Saudi;

2. Melanggar masa berlaku visa; atau

3. Terancam keamanan dan keselamatannya.

5. Sanksi Penyelenggara Perjalanan Ibadah Umrah

Menurut Pasal 41 Peraturan Menteri Agama Republik Indonesia Nomor 8 tahun 2018 tentang Penyelenggaraan Perjalanan Ibadah Umrah, mengenai sanksi bagi penyelenggara 
perjalanan umrah yang tidak memenuhi kewajibannya sebagaimana yang telah diatur dalam peraturan perundang-undangan, sanksi yaitu berupa :

1) PPIU yang melanggar ketentuan sebagaimana dimaksud dalam Pasal 7 ayat (1), Pasal 8 ayat (2) dan ayat (3), Pasal 10 ayat (2), Pasal 11 ayat (2), ayat (4), ayat (5), ayat (6), ayat (7), ayat (8), dan/atau ayat (9), Pasal 12, Pasal 14 ayat (3), ayat (5) dan ayat (6), Pasal 15, Pasal 16, Pasal 17, Pasal 18, Pasal 20, Pasal 21, Pasal 22, Pasal 23, dan Pasal 26 dikenakan sanksi peringatan tertulis.

2) PPIU yang melakukan pengulangan pelanggaran sebagaimana dimaksud pada ayat (1) dikenakan sanksi pembekuan izin penyelenggaraan paling lama 2 (dua) tahun.

3) PPIU yang melanggar ketentuan sebagaimana dimaksud dalam Pasal 24 dan Pasal 25 dikenakan sanksi pencabutan izin penyelenggaraan.

4) Dalam hal PPIU meminjamkan legalitas perizinan umrah kepada pihak lain untuk menyelenggarakan perjalanan ibadah umrah, dikenakan sanksi pencabutan izin penyelenggaraan.

5) Provider visa yang melanggar ketentuan sebagaimana dimaksud dalam Pasal 27 ayat (3) dikenakan sanksi, tidak dapat diberikan pengesahan kontrak sebagai syarat menjadi provider visa untuk paling lama 2 (dua) kali musim umrah.

6) Apabila izin operasional sebagai biro perjalanan wisata dicabut oleh Menteri yang menyelenggarakan urusan di 
bidang pariwisata, Gubernur, Bupati/Wali Kota, izin penyelenggaraan umrah dicabut.

7) Dalam hal dikenakan sanksi pembekuan atau pencabutan, PPIU wajib mengembalikan BPIU kepada Jemaah.

\section{F. Tanggung Jawab Hukum Biro Perjalanan Umrah Terhadap Calon Jamaahnya}

Tanggung jawab hukum adalah kewajiban untuk menanggung suatu akibat menurut ketentuan hukum yang berlaku. Disini, ada norma atau peraturan hukum yang mengatur tentang tanggung jawab. Ketika, ada perbuatan yang melanggar norma hukum itu, maka pelakunya dapat dimintai pertanggungjawaban sesuai dengan norma hukum yang dilanggarnya. Dalam konteks ini, istilah pertanggungjawaban hukum lebih tepat digunakan, karena menunjukkan adanya perbuatan yang dapat dimintai tanggung jawab melalui prosedur hukum dengan mengajukan tuntutan pidana atau gugatan perdata. Meskipun demikian, kedua istilah ini kadang-kadang digunakan secara bergantian, karena memiliki kesamaan makna. ${ }^{22}$

Prinsip Tanggung Jawab berdasarkan Wanprestasi (Breach Of Warranty) Tanggung jawab produsen berdasarkan wanprestasi juga merupakan bagian dari tanggung jawab bedasarkan kontrak (contractual liability). Dengan demikian, suatu produk yang rusak dan mengakibatkan kerugian, maka konsumen melihat isi kontrak, baik tertulis maupun tidak tertulis. Keuntungan pada prinsip ini penerapan kewajiban yang sifatnya mutlak (srict obligation), yaitu kewajiban yang didasarkan pada upaya yang telah dilakukan produsen untuk memenuhi janjinya. Artinya

\footnotetext{
${ }^{22}$ Tim Penyusun Kamus Pusat Pembinaan dan Pengembangan Bahasa, Kamus Besar Bahas Indonesia, Edisi Kedua, cet 1, Jakarta: Balai Pustaka, 1991, hlm. 1006, dalam Wahyu Sasongko, Op. Cit., hlm. 97.
} 
walaupun produsen telah berupaya memenuhi kewajiban dan janjinya, tetapi konsumen tetap mengalami kerugian, maka produsen tetap dibebani tanggung jawab untuk mengganti kerugian. Namun adapula kelemahan dalam teori prinsip ini, adanya pembatasan waktu gugatan, persyaratan pemberitahuan, kemungkinan adanya bantahan (disclaimer), dan persyaratan hubungan kontrak. $^{23}$ Prinsip tanggung jawab ini terbagi menajdi dua, yaitu :

a. Tanggung jawab berdasarkan jaminan produk yang tertulis (express warranty).

b. Tanggung jawab berdasarkan jaminan produk yang tidak tertulis (implied warranty).

Pertanggung jawaban Biro perjalanan umrah sebagai pelaku usaha apabila terjadi kerugian pada jamaah, diatur dalam ketentuan peraturan perundang-undangan, yaitu:

a. Menurut Kitab Undang-Undang Hukum Perdata (KUHPdt) Pertanggunjawaban dalam bidang hukum perdata, dapat ditimbulkan karena wanprestasi dan karena perbuatan melawan hukum (onrech matigedaad). Wanprestasi terjadi jika Biro perjalanan umrah tidak melaksanakan kewajibannya, yaitu tidak memberikan prestasi sebagaimana yang telah disepakati. Wanprestasi artinya tidak memenuhi sesuatu yang diwajibkan seperti yang telah ditetapkan dalam perikatan. Tidak terpenuhi kewajiban oleh perusahaan jasa perjalanan disebabkan oleh dua kemungkinan alasan, yaitu:

\footnotetext{
${ }^{23}$ Inosentius Samsul, Perlindungan Konsumen Kemungkinan Penerapan Tanggung Jawab Mutlak, Universitas Indonesia, Jakarta, 2004, hlm. 46, dalam Zulham, Hukum Perlindungan Konsumen, Kencana Prenanda Media Group, Jakarta, 2013, hlm. 83.
} 
1) Kemungkinan kesalahan/kelalaian yang dilakukan perusahaan jasa perjalanan, sehingga tidak terpenuhi kewajibannya;

2) Karena keadaan memaksa (overmacht), force majeure, jadi di luar kemampuan dari perusahaan jasa perjalanan.

Untuk menentukan apakah biro perjalanan umrah bersalah melakukan wanprestasi, perlu ditentukan dalam keadaan bagaimana biro perjalanan umrah tersebut dinyatakan sengaja atau lalai memenuhi prestasi. Ada tiga keadaan, yaitu:

1. Biro perjalanan umrah tidak memenuhi prestasi sama sekali;

2. Biro perjalanan umrah memenuhi prestasi, namun tidak baik atau keliru;

3. Biro perjalanan umrah memenuhi prestasi, namun tidak tepat waktu atau terlambat.

Setiap jamaah berhak menuntut ganti rugi terhadap biro perjalanan umrah yang menimbulkan kerugian akibat kesalahan atau kelalaian. Ketentuan mengenai tata cara pengajuan tuntutan adalah sesuai dengan ketentuan undang-undang yang berlaku. Berkaitan dengan gugatan seseorang dalam hal wanprestasi ada beberapa hal yang perlu diketahui:

1. Hanya dapat ditujukan pada pihak dalam perjanjian;

2. Kewajiban pembuktian dalam gugatan wanprestasi dibebankan kepada penggugat (dalam hal ini adalah pengguna jasa) yang menggugat wanprestasi.

Jamaah yang menggugat wanprestasi. Selain wanprestasi, pertanggungjawaban dalam hukum perdata juga dapat disebabkan karena adanya perbuatan melawan hukum. Perbuatan melawan hukum terjadi jika memenuhi beberapa persyaratan: 
1. Bertentangan dengan kewajiban hukum si pelaku;

2. Melanggar hak orang lain;

3. Melanggar kaidah tata usaha;

4. Bertentangan dengan asas kepatutan, ketelitian serta sikap kehati-hatian yang seharusnya dimiliki seseorang dalam pergaulan dengan sesama warga masyarakat atau terhadap harta benda orang lain.

Dalam ilmu hukum dikenal tiga kategori dari perbuatan melawan hukum, yaitu sebagai berikut:

1. Perbuatan melawan hukum karena kesengajaan (Pasal 1365 KUH Perdata);

2. Perbuatan melawan hukum tanpa kesalahan/tanpa unsur kesengajaan maupun $\backslash$ kelalaian (Pasal 1366 KUH Perdata);

3. Perbuatan melawan hukum karena kelalaian (Pasal 1367 KUH Perdata).

Jika dihubungkan dengan prinsip tanggung jawab dalam hukum, maka tanggung jawab dalam hal adanya wanprestasi dan perbuatan melawan hukum termasuk kedalam prinsip tanggung jawab berdasarkan kesalahan.

b. Menurut Pasal 41 ayat 7 Peraturan Menteri Agama Republik Indonesia Nomor 8 tahun 2018 tentang Penyelenggaraan Perjalanan Ibadah Umrah, Dalam hal dikenakan sanksi pembekuan atau pencabutan, Penyelengara Perjalanan Ibadah Umrah (PPIU) wajib mengembalikan Biaya Penyelenggaraan Ibadah Umrah (BPIU) kepada Jemaah.

\section{G. Akibat Hukum Atas Gagal Berangkatnya Calon Jamaah Umrah Yang Diakibatkan Oleh Biro Perjalanan Umrah}


Pada Pasal 1243 Kitab Undang-Undang Hukum Perdata, Suatu perjanjian yang tidak dilaksanakan karena adanya suatu unsur kesalahan atau kelalaian yang pada prinsipnya suatu wanprestasi membutuhkan pernyataan lalai (somasi) dan tentang jangka waktu perhitungan ganti rugi yang dapat dituntut, serta jenis dan jumlah ganti rugi yang dapat dituntut dengan dalil wanprestasi. Kecuali, tidak dilaksanakan kontrak tersebut karena alasan-alasan force majeure, yang umumnya membebaskan pihak yang tidak memenuhi prestasi (untuk sementara atau untuk selama-lamanya).

Tindakan wanprestasi membawa konsekuensi terhadap timbulnya hak pihak yang dirugikan untuk menuntut pihak yang melakukan wanprestasi untuk menuntut ganti rugi. Sehingga, oleh hukum diharapkan tidak ada satu pihak pun yang dirugikan karena wanprestasi tersebut.

Wanprestasi dimulai pada saat pihak biro perjalanan ibadah umroh tidak melakukan kewajibannya sesuai dengan kesepakatan dan lalai melaksanakannya. Maka suatu wanprestasi biro perjalanan ibadah umroh, suatu perbuatan hukum yang menyebabkan salah satu pihak dirugikan serta berada dalam keadaan lalai sesuai dengan Pasal 1238 Kitab Undang-Undang Hukum Perdata dan keadaan lalai dari pihak penyelenggra ibadah umroh dengan adanya suatu pernyataan lalai dan telah diberi suatu peringatan tertulis tentang pemenuhan kewajibannya terhadap perjanjian.

Dalam hal ini akibat hukum yang terjadi karena gagal berangkatnya calon jamaah umrah yang diakibatkan oleh biro perjalanan umrah yaitu biro perjalanan umrah telah melanggar Pasal Pasal 65 ayat 1 Peraturan Pemerintah Republik Indonesia Nomor 79 tahun 2012 tentang Pelaksanaan Undang-Undang Nomor 13 tahun 2018 tentang Penyelenggaraan Ibadah Haji, diatur mengenai larangan bagi penyelenggara perjalanan ibadah umrah, untuk menelantarkan jemaah umrah yang mengakibatkan jemaah umrah: 
1. Gagal berangkat ke Arab Saudi;

2. Melanggar masa berlaku visa; atau

3. Terancam keamanan dan keselamatannya.

Sehingga biro perjalanan umrah dapat terkena sanksi sesuai dengan Peraturan Pemerintah Republik Indonesia Nomor 79 tahun 2012 tentang Pelaksanaan Undang-Undang Nomor 13 tahun 2018 tentang Penyelenggaraan Ibadah Haji, mengatur tentang sanksi terhadap penyelenggara perjalanan ibadah umrah yang tidak memenuhi kewajibannya sebagai penyelenggara, yaitu tercantum dalam Pasal 69 PP No.79 tahun 2012 yang berisi: Pelanggaran terhadap ketentuan sebagaimana dimaksud dalam Pasal 65 dikenai sanksi administratif berupa pencabutan izin penyelenggaraan.

Junto Pasal 41 ayat 7 Peraturan Menteri Agama Republik Indonesia Nomor 8 tahun 2018 tentang Penyelenggaraan Perjalanan Ibadah Umrah, mengenai sanksi bagi penyelenggara perjalanan umrah yang tidak memenuhi kewajibannya sebagaimana yang telah diatur dalam peraturan perundang-undangan, sanksi yaitu berupa : Dalam hal dikenakan sanksi pembekuan atau pencabutan, PPIU wajib mengembalikan BPIU kepada Jemaah.

Akibat hukum dari wanprestasi biro perjalanan ibadah umroh dalam suatu perjanjian baik dalam bentuk tertulis maupun tidak tertulis adalah sama kedudukannya dan apabila telah memenuhi ketentuan Pasal 1320 Kitab Undang-Undang Hukum Perdata maka perjanjian tersebut adalah sah. Sehingga, apabila terjadi wanprestasi atau tidak terpenuhinya prestasi akibat hukum terhadap penyelenggara ibadah umroh berupa sanksi administrasi sampai pencabutan izin dan penggantian rugi terhadap jemaah yang dirugikan.

\section{PENUTUP}

\section{A. Kesimpulan}


Berdasarkan pembahasan permasalahan pada bab sebelumnya maka dapat dikemukakan kesimpulan sebagai berikut:

1. Tanggung jawab biro perjalanan umrah terhadap jamaah yang mengalami kerugian akibat wanprestasi yang dilakukan biro perjalanan umrah merupakan bentuk tanggung jawab berupa ganti kerugian. Ganti kerugian tersebut diantaranya pengembalian uang yang setara dengan kerugian yang dialami konsumennya, mengganti jasa yang sejenis atau setara nilainya, dan memberikan kompensasi kepada jamaah yang dirugikan sebagai bentuk perminta maaf dari biro perjalanan umrah.

2. Akibat hukum dari gagal berangkatnya jamaah biro perjalanan ibadah umroh dalam suatu perjanjian baik dalam bentuk tertulis maupun tidak tertulis adalah sama kedudukannya dan apabila telah memenuhi ketentuan Pasal 1320 Kitab Undang-Undang Hukum Perdata maka perjanjian tersebut adalah sah. Sehingga, apabila terjadi wanprestasi atau tidak terpenuhinya prestasi akibat hukum terhadap penyelenggara ibadah umroh berupa sanksi administrasi sampai pencabutan izin dan penggantian rugi terhadap jemaah yang dirugikan.

\section{B. Saran}

Berdasarkan kesimpulan di atas, maka saran yang dapat diberikan adalah sebagai berikut:

1. Kepada Jamaah diharapkan agar lebih berhati-hati dalam mengambil keputusan untuk memilih paket promo yang ditawarkan oleh biro perjalanan umrah dan hendaknya jamaah mencari tahu legalitas dari biro perjalanan umrah yang telah dipilih, serta meminta bentuk perjanjian yang secara tertulis mengenai hal yang diperjanjikan. Hal ini dilakukan untuk menghindari timbulnya kerugian bagi jamaah selaku biro perjalanan umrah.

2. Kepada Pemerintah khususnya Kementerian Agama Republik Indonesia untuk Meningkatkan pengawasan penyelenggaraan umrah. 
Pengawasan ini dilakukan karena banyaknya biro perjalanan umrah yang menyediakan layanan umrah di indonesia, saat ini pemerintah lebih fokus pada penyelenggaraan ibadah haji sehingga menyerahkan penyelenggaraan umrah melalui biro perjalanan umrah. Sementara, kementerian agama hanya berwenang memberikan izin usaha. Adapun yang menjadikan faktor-faktor menyebabkan lemahnya pengawasan oleh kementerian agama terhadap penyelenggaraan ibadah umroh ialah izin biro perjalanan umroh, dan aturan yang belum mampu untuk memenuhui perlindungan hukum terhadap jamaah.

3. Kepada biro perjalanan umrah diharapkan lebih memperhatikan hak dan kewajibannya sebagai penyelenggara perjalanan ibadah umrah, sehingga kedepan tidak lagi terjadi wanprestasi dan membuat perjanjian secara tertulis dengan jemaah sehingga jelas perjanjian yang sudah di perjanjikan bersama. Serta tidak melakukan promosi harga yang tidak bertanggung jawab demi meningkatkan penjualan perusahaan.

\section{DAFTAR PUSTAKA}

\section{A. Buku}

Hamzah, Andi. Kamus Hukum, (Ghalia Indonesia, 2005).

Harahap, Yahya. Beberapa Tinjauan Mengenai Sistem Peradilan dan Penyelesaian Sengketa, (Bandung: Citra Aditya Bakti, 1997).

Harahap, M.Yahya. Segi-Segi Hukum Perjanjian, (Bandung: Alumni, 1986).

Kalsen, Hans. Teori Umum tentang Hukum dan Negara, (Bandung : PT. Raja Grafindo Persada, 2006).

Muhammad, Abdul Kadir. Hukum dan Penelitian Hukum, (Bandung: PT. Citra Aditya, 2004).

Muhammad, Abdul Kadir. Hukum Perusahaan Indonesia, (Bandung: PT. Citra Aditya Bakti, 2010).

Rahardjo, Satjipto. Ilmu Hukum, (Bandung: PT. Citra Aditya Bakti, 2000). 
Rusli, Hardijan. Hukum Perjanjian Indonesia dan Common law, (Jakarta :

Sinar Harapan, 1996).

Salim, H.S., Hukum Kontrak Teori dan Tehnik Penyusunan Kontrak, (Jakarta: Sinar Grafika, 2004).

Samsul, Inosentius. Perlindungan Konsumen Kemungkinan Penerapan Tanggung Jawab Mutlak, Universitas Indonesia, (Jakarta : Prenanda Media Group, 2004).

Simanjuntak, P.N.H. Pokok-Pokok Hukum Perdata Indonesia, Cetakan ke-1. (Jakarta: Djambatan, 1999).

Soekanto, Soerjono. Pengantar Penelitian Hukum, Cetakan Ketiga. (Jakarta: UI Press, 1986).

Subekti. Hukum Perjanjian, ( Jakarta: PT. Intermasa, 2002).

Subekti. Pokok-Pokok Hukum Perdata, Cetakan ke-18. (Jakarta: PT. Intermasa, 2008).

\section{B. Peraturan Perundang-Undangan}

Indonesia. Undang-Undang Nomor 13 Tahun 2008 Tentang Penyelenggaraan Perjalanan Ibadah Haji (Lembaran Negara Republik Indonesia Tahun 2008 Nomor 60, Tambahan Lembaran Negara Republik Indonesia Nomor 4845).

. Peraturan Pemerintah Nomor 79 Tahun 2012 tentang Pelaksanaan Undang-Undang Nomor 13 Tahun 2008 tentang Penyelenggaraan Ibadah Haji (Lembaran Negara Republik Indonesia Tahun 2012 Nomor 186, Tambahan Lembaran Negara Republik Indonesia Nomor 5345).

- Peraturan Menteri Agama Nomor 8 Tahun 2018 Tentang Penyelenggaraan Perjalanan Ibadah Umrah (Lembaran Negara Republik Indonesia Tahun 2018 Nomor 366, Tambahan Lembaran Negara Republik Indonesia Nomor 4845).

. Kitab Undang-Undang Hukum Perdata..

\section{Internet}


Kementerian Agama, "Rata-Rata Jemaah Umrah Brangkat Perhari 195 Orang," https://haji.kemenag.go.id/v3/content/rata-rata-jemaah-umrahberangkat perhari-195-orang. Diakses pada 5 April 2018

Badan Pusat Statistik, "Jumlah Jamaah Umrah Tahun 2015," https://www.bps.go.id/linkTableDinamis/view/id/894. Diakses pada 5 April 2018 